\title{
Investigation of shock-wave initiation in metal- teflon powder mixtures
}

\author{
I. V. Saikov ${ }^{\dagger}$, M. I. Alymov, S. G. Vadchenko, I. D. Kovalev \\ †revan.84@mail.ru \\ Merzhanov Institute of Structural Macrokinetics and Materials Science of RAS, Academician Osipyan str., 8, \\ Chernogolovka, 142432, Russia
}

\begin{abstract}
The article is aimed at studying features and conditions of initiation, reaction, and final phase formation in the energetic condensed metal-teflon systems under shock wave loading. Thermodynamic calculations were carried out using the TERMO program. 16 different mixtures were made on the basis of the calculations. The adiabatic combustion temperatures, the composition and quantity of condensed products and the volume of gaseous products were calculated. To increase the combustion temperature, teflon powder was used as one of the components. The calculations showed that the compositions provided a sufficiently wide range of adiabatic combustion temperatures from $1190^{\circ} \mathrm{C}$ for $\mathrm{Cu}-\mathrm{Al}-\mathrm{C}_{2} \mathrm{~F}_{4}$ composition to $3280^{\circ} \mathrm{C}$ for $\mathrm{Hf}-\mathrm{B}-\mathrm{C}_{2} \mathrm{~F}_{4}$. The compositions based on $\mathrm{Ni}-\mathrm{Al}, \mathrm{Cu}-\mathrm{Al}$ and $\mathrm{Nb}-\mathrm{Al}$ with teflon differed in predominance of liquid phase in the products at relatively low combustion temperatures $\left(1740^{\circ} \mathrm{C}, 1190^{\circ} \mathrm{C}\right.$ and $1410^{\circ} \mathrm{C}$, respectively). Shock-wave loading of the samples was carried out in a multi-cell matrix by throwing a flyer. The acceleration of the flyer was carried out by detonation of the explosive. The detonation was initiated by an electric detonator located in the center along the assembly axis. Thus, the design of the recovery fixture provided the same loading conditions in all the cells. Ni-Al, Ni-Al- $\mathrm{C}_{2} \mathrm{~F}_{4}, \mathrm{Ti}-\mathrm{B}-\mathrm{C}_{2} \mathrm{~F}_{4}, \mathrm{Hf}-\mathrm{B}-\mathrm{C}_{2} \mathrm{~F}_{4}$ systems reacted most completely. Thus, the systems based on metals (titanium and hafnium) with additives of boron and teflon are the most promising ones to be used as a reaction material from the viewpoint of the achieved synthesis temperature, initiation by shock-wave action and the reaction completeness.
\end{abstract}

Keywords: reactive materials, shock-wave initiation, synthesis.

\section{Introduction}

Development of new energetic condensed systems (reactive materials) based on the mixtures of metals and their oxides with inorganic and polymer oxidizing compounds is one of the actual directions of applied investigation. These investigations, as a rule, are purely experimental $[1,2]$. They are characterized by the complexity of studying fastacting physico-chemical processes directly in the process of explosive loading, which is characterized by high velocities of deformation, pressures and temperatures. Peculiarities of solid-phase synthesis in aluminum-sulfur and aluminumfluoroplast mixtures in cylinder ampoules under explosive loading have been studied in experiments and numerically. It was found that pressure is increased sharply at the bottom of the ampoule when shock wave is reflected from the bottom ampoule lid as a compressive wave which is followed by chemical transformation rate growth. High rate of heat release during reaction in a lower ampoule part resulted in gas phase formation which leads to a further pressure increase and becomes the reason of ampoules destruction [2-4]. Detonation in an aluminum-fluoroplastic-4 (Teflon) mixture was studied experimentally in $[5,6]$. To increase reactivity, the initial mixture is pretreated in a mechanochemical activator. The action of a shock wave on a sample initiates the steady detonation regime, in which the initial and final substances are in the condensed state. The results prove that it is possible in principle to reach the steady detonation regime in reactive condensed mixtures forming final reaction products in the solid state. Up-to-date energetic materials of high efficiency must form the basis for future technologies in industry and military engineering $[7,8]$.

This work is aimed at studying features and conditions of initiation, reaction, and final phase formation in the energetic condensed metal-teflon systems under shock wave loading. In order to initiate combustion in powder mixtures, it is necessary to supply a thermal impulse to the substance local volume on the sample surface and reach the melting point of one of the components. The initiating thermal impulse must be rather powerful to warm-up the green mixture layer of the thickness comparable to the width of Michelson zone. For most SHS compositions this width makes $0.3-1 \mathrm{~mm}$ [9]. At impact inelastic compression adiabatic warming-up occurs since the heat can't leave the compressed body fast. As a rule, rather high pressures are required for synthesis realization; in other cases the initiation takes place in local volumes [1]. Besides at explosive initiation of the exothermic reaction, it can occur in high-speed and fast mode $[2,6]$.

\section{Methods}

Approximate thermodynamic calculations were carried out using the TERMO program [10]. 16 different mixtures were made according to the calculations. The adiabatic 
combustion temperatures, the composition and quantity of the condensed products and the volume of gaseous ones were calculated. To increase the combustion temperature, Teflon powder was used as a component. Its application also increases the strength of pressed powder items and its high cold plasticity makes the process of item production with relatively uniform density by the volume easier.

For the preparation of mixtures of metals with Teflon, the following components were used: Teflon powder F-4NTD-2 $(d<5 \mu \mathrm{m}), \mathrm{W}-\mathrm{PV}$ with the average particle size $d<6 \mu \mathrm{m}$, Al-ASD-1 with $d<10 \mu \mathrm{m}$, Ti-PTM with $d<40 \mu \mathrm{m}$, Hf-GF-N with $d<5 \mu \mathrm{m}$, Ta-TPM with $d<10 \mu \mathrm{m}, \mathrm{Ni}-\mathrm{PNE}-1$ with $d<71 \mu \mathrm{m}, \mathrm{Cu}-\mathrm{PMS}-\mathrm{V}$ with $d=45-100 \mu \mathrm{m}, \mathrm{Nb}-\mathrm{NB} 1$ $d<50 \mu \mathrm{m}$ and amorphous black boron V99-A. In a sample No. 7 nanopowders (Alex) of aluminum with $d \approx 50-70 \mathrm{~nm}$ and nickel with $d \approx 70-80 \mathrm{~nm}$ were used. Mixtures in a predetermined ratio were prepared in the mixer type "Turbula" with steel balls for 1 hour with the mass ratio of the mixture to the mass of the balls $1: 10$. The mixture No. 8 was prepared using an AGO-2 mechanical activator in a hexane medium under the motion acceleration of balls of $60 \mathrm{~g}$ for $5 \mathrm{~min}$. The ratio of the mass of the mixture to the mass of balls was $1: 20$. The volume of the drum was $150 \mathrm{~cm}^{3}$.

A method with a flat multi-cell recovery fixture was used to initiate the reactive material combustion by shock wave (Fig. 1) [11]. The experimental scheme used differs from the commonly used loading schemes by a plane shock wave [12]. In the present paper, the loading was carried out by a sliding shock wave. Blind holes (cells) of $10 \mathrm{~mm}$ in diameter were made in the steel matrix equidistant from the center to place initial prepressed billets. The diameter and thickness of the matrix were 100 and $15 \mathrm{~mm}$, respectively. Shock-wave loading was carried out by throwing a steel flyer $(4 \mathrm{~mm})$ on the matrix and sample surface by the charge of an explosive (hexogen). The velosity of the flyer was about $1 \mathrm{~km} / \mathrm{s}$. The velosity calculation was carried out similarly to calculations for explosive welding [13]. The movement of the flyer is similar to the flying plates during explosive welding. The detonation was initiated by an electric detonator located in the center by the assembly axis. The flyers didn't collapse during the experiment. Thus, the design of the fixture provided the same loading conditions in all the cells.

After the explosive detonation the products were removed from the matrix cells and subjected to X-ray phase analysis

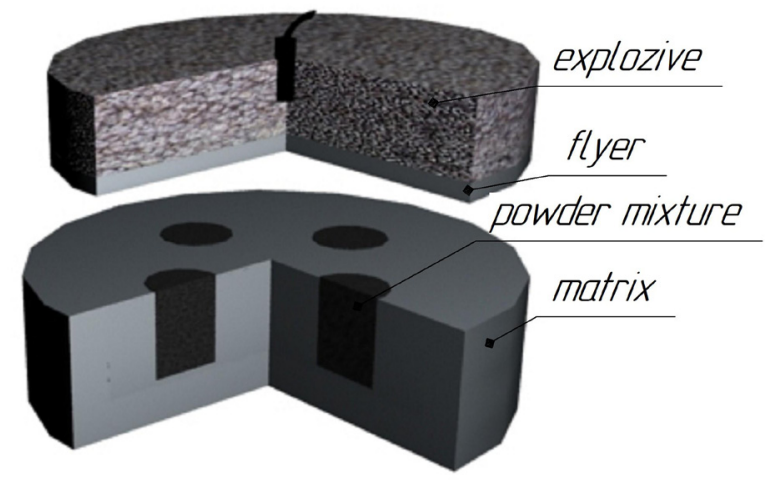

Fig. 1. Scheme of shock-wave processing of mixtures by throwing a flyer. using DRON-3M diffractometer $\left(\mathrm{Cu}_{\mathrm{K} \alpha}\right.$ radiation) with the angle step of $0.02^{\circ}$ and exposure time of $1 \mathrm{~s}$. X-ray phase analysis was carried out using the program «Crystallographica Search-Match». The quantitative analysis was carried out by the method of reference intensity ratio (RIR).

\section{Results and discussion}

The mixture compositions and characteristics, calculated and actual phase composition of the products are shown in Table 1.

The calculations showed that the compositions provided a sufficiently wide range of adiabatic combustion temperatures from $1190^{\circ} \mathrm{C}$ for $\mathrm{Cu}-\mathrm{Al}-\mathrm{C}_{2} \mathrm{~F}_{4}$ composition to $3280^{\circ} \mathrm{C}$ for Hf- $-\mathrm{C}_{2} \mathrm{~F}_{4}$ (lines 13 and 14 of Table 1 ). The compositions based on $\mathrm{Ni}-\mathrm{Al}, \mathrm{Cu}-\mathrm{Al}$ and $\mathrm{Nb}-\mathrm{Al}$ with Teflon differed in predominance of liquid phase in the products at relatively low combustion temperatures $\left(1740^{\circ} \mathrm{C}, 1190^{\circ} \mathrm{C}\right.$ and $1410^{\circ} \mathrm{C}$, respectively). Most of the compositions are characterized by the predominance of the solid component in the products.

The results of the X-ray analysis of the products are shown in Table 2.

Table 2 proves that the chemical reaction was initiated in most of the compositions subjected to shock wave processing by throwing a steel flyer. Only Ni-Al (No. 6) sample without teflon was completely preserved as a compact product. In all the other cells, most of the products were scattered. In some cells (samples $4,7,14,16$ ) it was impossible to collect the material for subsequent X-ray phase analysis because of its entire scattering.

It should be noted that, on the whole, the results of X-ray phase analysis correlate with the data on the initial composition of the samples. But in this case, the actually obtained percentage of phases in products is slightly different from the calculated ones. This is due to a number of assumptions in the program Thermo, which considers the reaction process as adiabatic. Calculation of equilibrium characteristics is based on minimizing of the system thermodynamic potential which expression accounts for the contributions of thermodynamic potentials for all the components present in the system, providing their concentrations. Algorithm for minimizing of the thermodynamic potential is based on the method of gradient descent [14]. Systems based on tungsten (No. 1, No. 2, No. 3 of Table 2) have shown themselves difficult to initiate under shock-wave loading. The X-ray phase analysis has recorded considerable $(54-85 \%)$ the tungsten rest with a small amount $(5-8 \%)$ of $\mathrm{W}_{2} \mathrm{C}$. The metal-additive ( $\mathrm{Al}$, $\mathrm{Hf}$ ) actively reacted with the fluorine from teflon with the formation of fluorides of $\mathrm{AlF}_{3}$ and $\mathrm{HfF}_{4}$. The interaction traces with teflon (carbides, fluorides) isn't revealed in products from mixtures based of nickel, copper and niobium (No. 12, No. 13 , No. 15, Table 2)

The most complete reaction (without a residue of the initial metal) was observed in compositions No. $6(\mathrm{Ni}-\mathrm{Al})$, No. 8 $\left(\mathrm{Ni}-\mathrm{Al}-\mathrm{C}_{2} \mathrm{~F}_{4} \mathrm{MA}\right)$, No. $10\left(\mathrm{Ti}-\mathrm{B}-\mathrm{C}_{2} \mathrm{~F}_{4}\right)$, No. $11\left(\mathrm{Hf}-\mathrm{B}-\mathrm{C}_{2} \mathrm{~F}_{4}\right)$ (Table 2). Compositions No. 6 and No. 8 have a relatively low adiabatic combustion temperature: $1640^{\circ} \mathrm{C}$ and $1740^{\circ} \mathrm{C}$, respectively. The main product in the compositions based on nickel and aluminum was $\mathrm{NiAl}$, the introduction of the teflon component resulted in the appearance of $\mathrm{AlF}_{3}$ in addition 
Table 1. Initial compositions, their density $(\rho)$, relative density (the ratio of actual density to theoretical) $\rho_{\text {rel }}$ calculated condensed products, adiabatic combustion temperature $\left(T_{a d},{ }^{\circ} \mathrm{C}\right)$, specific volume of gaseous products $\left(V_{g}\right.$, liter/g) and mass ratio of molten solid products $[M(L) / M(S)]$

\begin{tabular}{|c|c|c|c|c|c|c|c|}
\hline $\mathrm{N}$ & Mixture & $\rho, \mathrm{g} / \mathrm{cm}^{3}$ & $\rho_{\text {rel }}$ & $\begin{array}{c}\text { Condensed products, calculation, } \\
(\text { mole/weight } \%)^{*}\end{array}$ & $V_{g}$, liter/g & $M(L) / M(S)$ & $T_{a d},{ }^{\circ} \mathrm{C}$ \\
\hline 1 & $\begin{array}{l}\mathrm{W}-\mathrm{Al}-\mathrm{C}_{2} \mathrm{~F}_{4} \\
75-15-10\end{array}$ & 4.91 & 0.69 & $\begin{array}{c}\mathrm{Al}(\mathrm{L}) 0.36 / 4.9 ; \mathrm{W}_{2} \mathrm{C}(\mathrm{S}) 0.4 / 76 \\
\mathrm{~W}(\mathrm{~S}) 0.015 / 14\end{array}$ & 0.52 & 0.06 & 1370 \\
\hline 2 & $\begin{array}{l}\mathrm{W}-\mathrm{Ti}-\mathrm{C}_{2} \mathrm{~F}_{4} \\
75-15-10\end{array}$ & 5.65 & 0.67 & $\begin{array}{c}\mathrm{TiC}(\mathrm{S}) 0.044 / 13 ; \mathrm{W}_{2} \mathrm{C}(\mathrm{S}) ; 0.36 / 67.7 \\
\mathrm{Ti}(\mathrm{L}) 0.26 / 6 ; \mathrm{W}(\mathrm{S}) 0.02 / 9.4\end{array}$ & 0.35 & 0.07 & 2240 \\
\hline 3 & $\begin{array}{l}\mathrm{W}-\mathrm{Hf}-\mathrm{C}_{2} \mathrm{~F}_{4} \\
75-15-10\end{array}$ & 6.64 & 0.7 & $\begin{array}{c}\mathrm{HfC}(\mathrm{S}) 0.17 / 16 \\
\mathrm{~W}_{2} \mathrm{C}(\mathrm{S}) 0.23 / 44 ; \mathrm{W}(\mathrm{S}) 0.18 / 17\end{array}$ & 0.17 & 0 & 2090 \\
\hline 4 & $\begin{array}{l}\mathrm{W}-\mathrm{Ta}-\mathrm{C}_{2} \mathrm{~F}_{4} \\
75-15-10\end{array}$ & 8.25 & 0.77 & $\begin{array}{c}\mathrm{Ta}_{2} \mathrm{C}(\mathrm{S}) 0.003 / 0.6 ; \\
\mathrm{W}_{2} \mathrm{C}(\mathrm{S}) 0.4 / 75 ; \mathrm{W}(\mathrm{S}) 0.02 / 19.5\end{array}$ & 0.21 & 0 & 2730 \\
\hline 5 & $\begin{array}{c}\mathrm{Ni}-\mathrm{Al}-\mathrm{C}_{2} \mathrm{~F}_{4} \\
61.7-28.3-10\end{array}$ & 3.04 & 0.67 & $\begin{array}{c}\mathrm{NiAl}(\mathrm{L}) \text { 0.848/72.7; C(S) 0.2/2.4; } \\
\mathrm{Ni}(\mathrm{L}) 0.2 / 11.9\end{array}$ & 0.35 & 35.2 & 1740 \\
\hline 6 & $\begin{array}{c}\mathrm{Ni}-\mathrm{Al} \\
68.5-31.5 \\
\end{array}$ & 3.84 & 0.75 & $\begin{array}{c}\mathrm{NiAl}(\mathrm{L}) 0.42 / 42 \\
\mathrm{NiAl}(\mathrm{S}) \\
0.58 / 58 \\
\end{array}$ & 0 & 1.38 & 1640 \\
\hline 7 & $\begin{array}{c}\mathrm{Ni}-\mathrm{Al}-\mathrm{C}_{2} \mathrm{~F}_{4} \\
61.7-28.3-10 \text { nano }\end{array}$ & 2.94 & 0.65 & $\begin{array}{c}\mathrm{NiAl}(\mathrm{L}) \text { 0.848/72.7; C(S) 0.2/2.4; } \\
\mathrm{Ni}(\mathrm{L}) 0.2 / 11.9\end{array}$ & 0.35 & 35.2 & 1740 \\
\hline 8 & $\begin{array}{c}\mathrm{Ni}-\mathrm{Al}-\mathrm{C}_{2} \mathrm{~F}_{4} \\
61.7-28.3-10 \mathrm{MA} \\
\end{array}$ & 3.17 & 0.75 & $\begin{array}{c}\mathrm{NiAl}(\mathrm{L}) \text { 0.848/72.7; C(S) 0.2/2.; } \\
\mathrm{Ni}(\mathrm{L}) \text { 0.2/11.9 } \\
\end{array}$ & 0.35 & 35.2 & 1740 \\
\hline 9 & $\begin{array}{l}\mathrm{Hf}-\mathrm{Al}-\mathrm{C}_{2} \mathrm{~F}_{4} \\
75-15-10\end{array}$ & 5.23 & 0.83 & $\begin{array}{c}\mathrm{Al}(\mathrm{L}) 0.24 / 3.3 ; \mathrm{HfC}(\mathrm{S}) 0.4 / 38 \\
\mathrm{Hf}(\mathrm{S}) 0.44 / 39\end{array}$ & 0.84 & 0.04 & 2030 \\
\hline 10 & $\begin{array}{l}\mathrm{Ti}-\mathrm{B}-\mathrm{C}_{2} \mathrm{~F}_{4} \\
70-20-10\end{array}$ & 2.29 & 0.66 & $\begin{array}{l}\operatorname{TiB}_{2}(\mathrm{~L}) \text { 0.34/24; } \mathrm{TiB}(\mathrm{S}) 0.3 / 18 \\
\mathrm{TiB}_{2}(\mathrm{~S}) \text { 0.42/29; } \mathrm{TiC}(\mathrm{S}) 0.2 / 12\end{array}$ & 0.6 & 0.4 & 2920 \\
\hline 11 & $\begin{array}{l}\mathrm{Hf}-\mathrm{B}-\mathrm{C}_{2} \mathrm{~F}_{4} \\
75-15-10\end{array}$ & 3.19 & 0.53 & $\begin{array}{c}\mathrm{HfB}_{2}(\mathrm{~L}) 0.25 / 28 ; \mathrm{HfC}(\mathrm{S}) 0.4 / 42 ; \\
\mathrm{Hf}(\mathrm{L}) 0.18 / 18\end{array}$ & 0.65 & 1.1 & 3280 \\
\hline 12 & $\begin{array}{l}\mathrm{Ni}-\mathrm{B}-\mathrm{C}_{2} \mathrm{~F}_{4} \\
80-10-10\end{array}$ & 3.87 & 0.69 & $\begin{array}{c}\mathrm{B}_{4} \mathrm{C}(\mathrm{S}) 0.08 / 4.4 ; \mathrm{NiB}(\mathrm{S}) 0.48 / 33 ; \\
\mathrm{C}(\mathrm{S}) 0.12 / 1.5 ; \mathrm{Ni}(\mathrm{L}) 0.88 / 52\end{array}$ & 0.24 & 1.3 & 1600 \\
\hline 13 & $\begin{array}{c}\mathrm{Cu}-\mathrm{Al}-\mathrm{C}_{2} \mathrm{~F}_{4} \\
60-30-10 \\
\end{array}$ & 3.09 & 0.69 & $\mathrm{Al}(\mathrm{L}) 0.62 / 16.7 ; \mathrm{Cu}(\mathrm{L}) 0.94 / 60$ & 0.24 & L100\% & 1190 \\
\hline 14 & $\begin{array}{c}\mathrm{Ti}-\mathrm{Cu}-\mathrm{C}_{2} \mathrm{~F}_{4} \\
60-30-10 \\
\end{array}$ & 3.32 & 0.71 & $\begin{array}{c}\mathrm{TiC}(\mathrm{S}) \text { 0.2/12; } \mathrm{Cu}(\mathrm{L}) \text { 0.47/30; } \\
\mathrm{Ti}(\mathrm{S}) \text { 0.49/23.4; } \mathrm{Ti}(\mathrm{L}) 0.42 / 20.4\end{array}$ & 0.23 & 1.4 & 1670 \\
\hline 15 & $\begin{array}{c}\mathrm{Nb}-\mathrm{Al}-\mathrm{C}_{2} \mathrm{~F}_{4} \\
50-40-10 \\
\end{array}$ & 3.44 & 0.69 & $\begin{array}{c}\mathrm{Nb}_{3} \mathrm{Al}(\mathrm{S}) 0.005 / 0.8 \\
\mathrm{NbAl}_{3}(\mathrm{~L}) 0.86 / 79 ; \mathrm{NbC}(\mathrm{S}) 0.2 / 11\end{array}$ & 0.28 & 6.7 & 1410 \\
\hline 16 & $\begin{array}{l}\mathrm{Ni}-\mathrm{Ti}-\mathrm{C}_{2} \mathrm{~F}_{4} \\
60-30-10\end{array}$ & 3.47 & 0.74 & $\mathrm{Ni}(\mathrm{L})$ 0.51/30; $\mathrm{Ti}(\mathrm{S})$ 0.91/44 & 0.22 & 0.7 & 1644 \\
\hline
\end{tabular}

${ }^{*} \mathrm{~L}$ - liquid; $\mathrm{S}$ - solid

Table 2. Results of X-ray phase analysis of products.

\begin{tabular}{|c|c|c|}
\hline $\mathrm{N}$ & Initial mixture (contents, weight \%) & X-ray phase analysis (contents, weight \%) \\
\hline 1 & $\mathrm{~W}(75)-\mathrm{Al}(15)-\mathrm{C}_{2} \mathrm{~F}_{4}(10)$ & $\mathrm{Al}(17) ; \mathrm{W}(54) ; \mathrm{W}_{2} \mathrm{C}(8) ; \mathrm{AlF}_{3}(21)$ \\
\hline 2 & $\mathrm{~W}(75)-\mathrm{Ti}(15)-\mathrm{C}_{2} \mathrm{~F}_{4}(10)$ & W (85); Ti (15); \\
\hline 3 & $\mathrm{~W}(75)-\mathrm{Hf}(15)-\mathrm{C}_{2} \mathrm{~F}_{4}(10)$ & $\mathrm{W}(71) ; \mathrm{W}_{2} \mathrm{C}(5) ; \mathrm{HfF}_{4}(24)$ \\
\hline 4 & $\mathrm{~W}(75)-\mathrm{Ta}(15)-\mathrm{C}_{2} \mathrm{~F}_{4}(10)$ & Product scattering \\
\hline 5 & $\mathrm{Ni}(61.7)-\mathrm{Al}(28.3)-\mathrm{C}_{2} \mathrm{~F}_{4}(10)$ & $\mathrm{NiAl}(8) ; \mathrm{Al}(44) ; \mathrm{Ni}(48)$ \\
\hline 6 & $\mathrm{Ni}(68.5)-\mathrm{Al}(31.5)$ & $\mathrm{NiAl}(89) ; \mathrm{Ni}_{2} \mathrm{Al}_{3}(11)$ \\
\hline 7 & $\mathrm{Ni}(61.7)-\mathrm{Al}(28.3)-\mathrm{C}_{2} \mathrm{~F}_{4}(10)$ nano & Product scattering \\
\hline 8 & $\mathrm{Ni}(61.7)-\mathrm{Al}(28.3)-\mathrm{C}_{2} \mathrm{~F}_{4}(10) \mathrm{MA}$ & $\mathrm{NiAl}(74) ; \mathrm{AlF}_{3}(9) ; \mathrm{Ni}_{2} \mathrm{Al}_{3}(17)$ \\
\hline 9 & $\mathrm{Hf}(75)-\mathrm{Al}(15)-\mathrm{C}_{2} \mathrm{~F}_{4}(10)$ & $\mathrm{Hf} ; \mathrm{HfC}^{*}$ \\
\hline 10 & $\mathrm{Ti}(70)-\mathrm{B}(20)-\mathrm{C}_{2} \mathrm{~F}_{4}(10)$ & $\mathrm{TiC} ; \mathrm{TiB}_{2}{ }^{*}$ \\
\hline 11 & $\mathrm{Hf}(75)-\mathrm{B}(15)-\mathrm{C}_{2} \mathrm{~F}_{4}(10)$ & $\mathrm{HfB}_{2}(100)$ \\
\hline 12 & $\mathrm{Ni}(80)-\mathrm{B}(10)-\mathrm{C}_{2} \mathrm{~F}_{4}(10)$ & $\mathrm{Ni}(95) ; \mathrm{Ni}_{2} \mathrm{~B}(5)$ \\
\hline 13 & $\mathrm{Cu}(60)-\mathrm{Al}(30)-\mathrm{C}_{2} \mathrm{~F}_{4}(10)$ & $\mathrm{Al}(41) ; \mathrm{Cu}(43) ; \mathrm{CuAl}_{2}(9) \mathrm{Cu}_{9} \mathrm{Al}_{4}(7)$ \\
\hline 14 & $\mathrm{Ti}(60)-\mathrm{Cu}(30)-\mathrm{C}_{2} \mathrm{~F}_{4}(10)$ & Product scattering \\
\hline 15 & $\mathrm{Nb}(50)-\mathrm{Al}(40)-\mathrm{C}_{2} \mathrm{~F}_{4}(10)$ & $\mathrm{Nb}(12) ; \mathrm{Al}(85) ; \mathrm{NbAl}_{3}$ (3) \\
\hline 16 & $\mathrm{Ni}(60)-\mathrm{Ti}(30)-\mathrm{C}_{2} \mathrm{~F}_{4}(10)$ & Product scattering \\
\hline
\end{tabular}

${ }^{\star}$ Due to the presence of unidentified peaks, the quantitative calculation could not be carried out 
to $\mathrm{NiAl}$ and $\mathrm{Ni}_{2} \mathrm{Al}_{3}$. It is important to note that two systems No. $10\left(\mathrm{Ti}-\mathrm{B}-\mathrm{C}_{2} \mathrm{~F}_{4}\right)$ and No. $11\left(\mathrm{Hf}-\mathrm{B}-\mathrm{C}_{2} \mathrm{~F}_{4}\right)$ are the most advantageous from the viewpoint of energy release; their adiabatic combustion temperatures are $2920^{\circ} \mathrm{C}$ and $3280^{\circ} \mathrm{C}$, respectively.

Therefore, the systems based on metals (titanium and hafnium) with additives of boron and teflon are the most promising ones to be used as reaction materials in special equipment from the viewpoint of the achieved synthesis temperature, initiation by shock-wave action and reaction completeness.

Acknowledgements. The reported study was funded by RFBR according to the research project № 16-03-00777 $a$.

\section{References}

1. M. I. Alymov, S. G. Vadchenko, I. V. Saikov, I. D. Kovalev. Inorganic Materials: Applied Research. 8 (2), 340 (2017).

2. S.A. Zelepugin, A. YU. Dolgoborodov, O.V. Ivanova, A.S. Zelepugin. Shock-wave synthesis in solid mixtures. Textbook. Tomsk, IAO SB RAS. (2012) 230 p. (in Russian) [C. А. Зелепугин, А. Ю. Долгобородов, О.В. Иванова, А.С. Зелепугин Ударно-волновой синтез в твердых смесях. Томск, Изд-во ИОА СО РАН. 2012. 230 с.].

3. O.V. Ivanova, S.A. Zelepugin Izvestiya vuzov. 55 (9-3), 46 (2012) (in Russian) [Иванова О.В., Зелепугин С.А. Известия высших учебных заведений. Физика, 55 (9-3), 46 (2012)].

4. S. A. Zelepugin, O. V. Ivanova. In: Concise Encyclopedia of Self-Propagating High-Temperature Synthesis: History, Technology, and Products, ed. by I.P. Borovinskaya, A.A. Gromov, E.A. Levashov, Yu.M. Maksimov, A.S. Mukasyan, A.S. Rogachev, Amsterdam, Netherlands; Oxford, United Kingdom; Cambridge, United States: Elsevier (2017) 466.
5. A. Yu. Dolgoborodov. Combustion, Explosion, and Shock Waves. 51 (1), 86 (2015).

6. A. Yu. Dolgoborodov, M. N. Makhov, I. V. Kolbanev A. N., Streletskii V.E. Fortov. Journal of Experimental and Theoretical Physics Letters. 81 (7), 311 (2005).

7. N.A. Imhovik, V.V. Selivanov, A.K. Simonov, A. I. Sergeeva, V.B. Jashin. Armament and Economics. 1 (26), 53 (2014). (in Russian) [Н.А. Имховик, В.В. Селиванов, А.К. Симонов, А.И. Сергеева, В.Б. Яшин. Вооружение и экономика. 1 (26), 53 (2014).]

8. N.A. Imkhovik, A.V. Svidinsky, A.S. Smirnov, V.B. Yashin. Gorenie i Vzryv (Moskva) - Combustion and Explosion. 10 (1), 93 (2017). (inRussian) [H.A. Имховик, А.В. Свидинский, А.С. Смирнов, В.Б. Яшин. Горение и взрыв. 10(1), 93 (2017)]

9. A.G. Merzshanov. Solid flame combustion. Textbook. Chernogolovka, ISMAN. (2000) 224 p. (in Russian) [А.Г. Мержанов. Твердопламенное горение. Черноголовка. ИСМАН. (2000) 224 с.]

10. A.A. Shiryaev. Thermodynamic of SHS: modern approach. Int. J. of SHS. 4 (4), 351 (1995).

11. M.I. Alymov, L.B. Pervukhin, A.S. Rogachev, O.L. Pervukhina, I.V. Saikov. Letters on materials. 4 (3), $153-158$ (2014). (in Russian) [М.И. Алымов, Л.Б. Первухин, А.С. Рогачев, О.Л. Первухина, И.В. Сайков. Письма о материалах. 4 (3), $153-158$ (2014).] DOI: 10.22226/2410-3535-2014-3-153-158

12. N. N. Thadhani, N. Chawla, W. Kibbe. Journal of materials science. 26, 232 (1991).

13. Yu. A. Konon, L.B. Pervukhin, A.D. Chudnovskii. Explosive welding. Textbook. Moscow, Mashinostroenie. (1987) 216 p. (in Russian) [Ю. А. Конон, Л. Б. Первухин, А.Д. Чудновский. Сварка взрывом. Москва, Машиностроение. (1987) 216 с.

14. http://www.ism.ac.ru/thermo/ 